\title{
Anmeldelser
}

Tips om medisinsk litteratur, andre bøker, filmer og elektroniske medier som bør anmeldes, sendes tidsskriftet@legeforeningen.no

\section{Slutten av livet}

Carlenius $\mathrm{S}$

\section{Omsorg ved livets slutt}

Møter med pasienter og pårørende. $139 \mathrm{~s}$. Bergen: Fagbokforlaget, 2008. Pris NOK 229 ISBN 978-82-450-0780-0

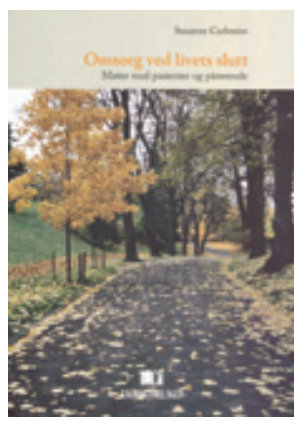

Forfatteren er teolog og sykepleier. Hun har arbeidet både i sykehjem og sykehus og de siste ni årene ved Hospice Lovisenberg, et sted for alvorlig syke og døende kreftpasienter i Oslo. Hun har et sterkt og dypt engasjement for sine pasienter og deres pårørende, og hun følger dem på deres vei til «den andre siden». I løpet av hennes ni år ved avdelingen har det vært ca. 1300 dødsfall.

Denne ganske lille utgivelsen er tenkt som lærebok for studenter i helsefag. Den består av 27 korte pasientfortellinger, en prolog og en epilog. I fortellingene gir forfatteren et tydelig og sterkt bilde av pasienter og pårørende, ofte med deres egne ord. Hun forteller om de kroppslige plagene og de psykiske og sosiale lidelsene. Det er ofte opprør mot alt det vonde, men mange finner frem til fred og forsoning. Det er selvfølgelig sterke følelser, og hun setter ord på dem på en god måte. Hele veien beskriver hun også sine egne følelser og refleksjoner.

Alle pasientene hadde kreft, og de fleste sto midt i livet da sykdommen rammet. Det reiser svære problemer for pasienter og pårørende, for de dør jo ofte fra små barn og fortvilte ektefeller. Samtidig er den medisinske omsorgen - palliasjonen - som regel mer utfordrende for denne pasientgruppen enn for andre døende. Tre firedeler av dem som dør i Norge er gamle mennesker som ikke dør av kreft, og de dør i vanlige sykehus og sykehjem. Hospiceomsorgen er et privilegert forbilde, og jeg savner refleksjoner over hvorledes forfatterens erfaringer bør brukes i resten av helseog omsorgstjenesten. Hun er teolog, og den kristne tro er selvfølgelig grunnleggende for henne. Jeg har dyp respekt for «troens gave», men de fleste i Norge har ikke fått den, og jeg savner også dette perspektivet.

Carlenius skriver levende og godt, og hennes refleksjoner er viktige for alle som arbeider med den vanskelige omsorgen ved livets slutt. Jeg tror at alle som har sitt virke på dette viktige feltet vil ha glede og nytte av å lese denne boken - flere ganger.

Peter F. Hjort

Blommenholm

\section{Gammel i 25 år}

Daatland SO, red

\section{Halve livet}

Artikler om aldring og livsløp. $361 \mathrm{~s}$ Bergen: Fagbokforlaget, 2008. Pris NOK 369 ISBN 978-82-450-0787-9

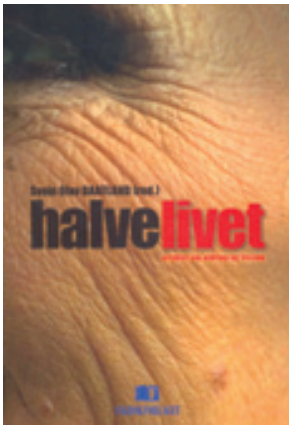

Tidsskriftet Aldring og Livsløp, tidligere Aldring og Eldre, enda tidligere Gerontologisk Magasin, feirer sine første 25 år med å gi ut utvalg av sine artikler. Hensikten med tidsskriftet er å «være en kanal mellom forskning,

fagfeltet, forvaltningen og folk flest».

Dermed er vi alle en del av målgruppen.

Halve livet inneholder i alt 50 artikler, samlet i fem bolker. Den første er en introduksjon skrevet av redaksjonen, som består av nestorene Svein Olav Daatland, Reidun Ingebretsen, Britt Slagsvold og Per Erik Solem. Et slikt firkløver borger for kvalitet.

Bolk 2 heter Utvikling og kriser. Her finner vi Sol Seims bokstavelig talt enestående studie av intelligens og personlighet over livsløpet. Tor Inge Romørens langtidsstudie av alle personer i Larvik som var over 80 år i 1981, som omhandler funksjonstap, familieomsorg og tjenestebruk frem til den siste døde i 1999, vil også bli stående som et referansearbeid i gerontologien. I denne bolken omtales også demens og død.

Bolk 3 heter Historiske røtter og handler om alders visdom og fysisk forfall. Sitat Eigil Skallagrimsson: «Stiv eg går og stabbar, skulle ottast falle, lite eg høyrer, og liten er lem som til lyst er laga.» Så følger sosial identitet, transnasjonal eldreomsorg, familien i endring, levekår og pensjonering. Skal vi glemme arven?

Bolk 4 handler om eldrepolitikken, vel- ferd, boformer, omsorg, kvalitet, standardisering. Wenche Frogn Sellæg tar opp spørsmålet om sykehjemmene fortsatt skal være både en behandlingsinstitusjon og bolig. Svaret er nei. Men da må man styrke både tilsynsfunksjonen og klagebehandlingen.

Bolk 5, Aldersforskningen, gir en betimelig påpekning av fallgruber i tolkingen av risikostatistikk - det er forskjell på gjennomsnitt og livsløp. Selv om bare 5-6\% av de eldre bor på institusjon og bare $5 \%$ lider av demens, er livsløpsrisikoen langt høyere dersom man blir over 80 år.

Gunhild O. Hagestad avrunder det hele med å peke fremover mot NorLAG-studien, der en bred database med opplysninger fra 5000 personer vil kunne gi mer innsikt i hvilke endringer som skjer over tid. De første resultatene begynner nå å komme.

Det kan være på sin plass. Forskningsrådet har nettopp avsluttet annen del av Velferdsprogrammet. Her er forskning på aldring og omsorg, velferdsstatens største utfordring i dag, tilgodesett med $4 \%$ av midlene.

Denne utgivelsen er nyttig og interessant, men ville ha stått seg på å være betydelig kortere. Det blir for mange repetisjoner, særlig i bolk 4. Der anbefales hurtiglesing.

\section{Astrid Nøklebye Heiberg \\ Oslo}

\section{Manual og arbeidsbok med liten overføringsverdi}

Tharaldsen KB, Otten $\mathrm{H}$.

\section{Mestringsteknikker for livsvansker}

Mindfulness-based coping - MbC-manual.

306 s, tab, ill. Stavanger: Hertervig forlag, 2008.

Pris NOK 280

ISBN 978-82-8216-026-1

Det er ikke mulig å skrive en oppskriftsbok på hvordan man kan mestre psykologiske utfordringer, har jeg ofte sagt til pasientene mine. Ettersom det er slik at vi mennesker ikke bare er rasjonelle, men også i høy grad irrasjonelle i tanker og atferd, har en slik bok aldri funnet sin forfatter. Dette er heller ikke en slik, til tross for forfatternes høye ambisjoner i tittelen - det er en manual for gruppeledere og samtidig en arbeidsbok for gruppedeltakere. Det omfatter fire temaer: oppmerksomhetstrening, stressmestring, affektregulering og relasjonshåndtering. 
Teksten er utformet som et kurs, utarbeidet ved Dalane distriktspsykiatriske senter i Stavanger, og er brukt som støtte ved siden av annen behandling, som medikamenter og individualterapi. Kurset er drevet som smågruppeundervisning, lederne er ansatte med pedagogikk eller ergoterapi som bakgrunn. Forfatterne er norske, men de bruker likevel mange engelske begreper, bl.a. «mindfulness», og ukjente ordkonstruksjoner som f.eks. «mindfulness-ferdigheter». Dette er et klart minus, gitt den overføringsverdi dette kursopplegget kunne ha hatt.

Jeg tviler ikke på at kurset fungerer utmerket hjemme i Stavanger, men jeg tviler på om heftet formidler nok kunnskap til at andre fagmiljøer kan ha særlig nytte av å bruke det. Utgivelsen er intern i sin form, samtidig som bruk av fremmede begreper bidrar til at nye kursledere nok vil ha store utfordringer med å gjøre denne manualen til sin egen. Som selvhjelpsbok fungerer den ikke.

Dalane DPS har satt $i$ gang et prisverdig undervisningsopplegg for sine pasienter. Andre poliklinikker kunne antakelig med fordel sette i gang med tilsvarende opplegg. Men jeg tror at poliklinikkene må finne sin egen form på et slikt undervisningsopplegg dersom det skal fungere godt. Derfor må jeg dessverre konkludere med at det er mye bortkastet energi som er lagt igjen mellom de stive permene.

\section{Synnøve Bratlie}

Synnøve Bratlies spesialistpraksis Oslo

\section{Vellykket bidrag til norsk medisinsk historie}

Bore RR, red

På liv og død

Helsestatistikk i 150 år. 266 s, tab, ill.

Oslo: Statistisk sentralbyrå, 2007. Pris NOK 300 ISBN 978-82-537-7293-6

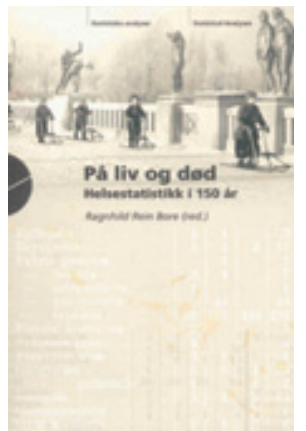

På liv og død består av 16 artikler fordelt på sju temabolker og gir smakebiter om helsestatistikk og helsetilstand i Norge i perioden 1800-2005.

Redaktøren håper at dette vil øke forståelsen for deler av norsk medisinsk

historie. Boken har et godt språk, oversiktlige tabeller og figurer og er rikt illustrert.

Først er det et temakapittel om opprettelse og utvikling av den offisielle helsesta- tistikken. Det andre temakapitlet om dødelighet og dødsårsaker er tredelt. Den første artikkelen gir en oversikt over dødelighet under demografisk og epidemiologisk overgang og etterfølges av en artikkel om utviklingen når det gjelder voldsomme dødsfall. Den tredje artikkelen bidrar til ny kunnskap. Ved bruk av arkivmateriale som var lukket inntil 2005, viser Robert Lalla at hvert femte utenriksdødsfall i årene 1939-45 som tidligere har vært kodet som krigsdødsfall, ikke var relatert til krigen. Lalla antar at 7000 døde, men arkivene innholder kun informasjon om 6200 personer. Frontkjempere og nordmenn som tjenestegjorde i marinen er trolig blant de underregistrerte.

I det tredje temakapitlet, om variasjon i dødelighet, er det først en oversiktsartikkel om sosial ulikhet i helse, deretter presenteres en ny analyse om dødelighet $\mathrm{i}$ by og land. Jens-Kristian Borgan konkluderer med at livet historisk sett var farligere $i$ byene enn på landet, og at trangboddhet i byene ga høyere risiko for å dø av tuberkulose og andre infeksjonssykdommer. Det er imidlertid flere faktorer enn trangboddhet som var av betydning for utviklingen fra smitte til klinisk sykdom (lungefunn) og død. Knut Liestøl, Steinar Tretli, Aage Tverdal og Jan Mæhlen viser f.eks. i fjerde temakapittel om sykdom at det i Oslo var en tuberkulosedødelighet på linje med landsgjennomsnittet og at dødeligheten var lav i forhold til smitte og lungefunn. Dette går imot forestillingen om tuberkulose som spesielt dødelig i byene. Risikoen for å bli smittet av sykdommen var riktignok høyere blant borgere og arbeidere i Oslo enn blant bønder på Hedemarken (figur 5, s. 129), men ernæringsog sykdomshistorie - som varierer med sosial status - var også viktige faktorer for å forklare forskjeller i smitterisiko, klinisk sykdom og dødelighet. Dersom Jens-Kristian Borgan hadde kontrollert for sosioøkonomiske karakteristika, kan det hende at trangboddhet $\mathrm{i}$ byene hadde fremstått som mindre farlig og at dødelighetsforskjellene mellom by og land i stor grad kunne forklares med sosial ulikhet. I tillegg til artikkelen om tuberkulose finnes i fjerde temakapittel også et bidrag til psykiatrihistorien.

Femte temakapittel består av tre artikler. Den første av disse handler ikke om forebyggende helsearbeid, som overskriften lover, men er derimot en oversiktsartikkel om årsaker til variasjon i høyde blant rekrutter. De to andre inneholder intervjuer med henholdsvis Aina Schiøtz, medforfatter av tobindsverket Det offentlige helsevesen i Norge 1603-2003, og Kjell Bjartveit, tidligere leder for Statens skjermbildefotografering. Sjette temakapittel beskriver den historiske utviklingen innen behandling i primær- og spesialisthelsetjenesten og utviklingen av forskjellige typer sykehus. Det hele avsluttes med to kapitler om det offentliges rolle innen tannhelse og helseutbygging.

Alt i alt er På liv og død vellykket. Den bidrar til økt forståelse for noen aspekter ved norsk helsehistorie. Artiklene er imidlertid svært varierende i form og kvalitet det er alt fra beskrivelser av tilgjengelige historiske helsedata via intervjuer og bidrag uten klar problemformulering til gode oversiktsartikler og ny forskning styrt av spørsmål i forskningsfronten. Det er uklart hvem man henvender seg til, men trolig appellerer På liv og død mer til generelt historieinteresserte enn til faghistorikere. Når det er sagt, kan den likevel egne seg for begynnerstudenter i historie, demografi, sykepleievitenskap eller medisin.

\section{Svenn-Erik Mamelund}

Divisjon for psykisk helse

Avdeling for helseovervåking og forebygging

Nasjonalt folkehelseinstitutt

\section{Håndbok i livsstyrketrening}

Stubhaug B.

\section{Når livet røyner på}

Livskriser og meistring. $95 \mathrm{~s}$.

Oslo: Det norske samlaget, 2008. Pris NOK 249

ISBN 978-82-521-7082-5

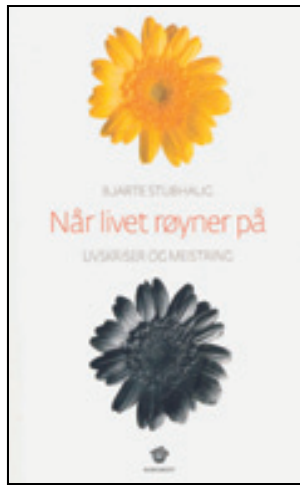

Livskriser kan dreie seg om motgang, nederlag og tap. Det kan være hendelser som oppleves som katastrofale for den enkelte men som likevel er en del av det livet byr på for mange. Det er i hovedsak de normale krisene og katastrofene mennesker har vært rammet av til alle tider som omhandles i denne utgivelsen. Innspill til perspektiv og mestring er intensjonen. Ekstremt traumatisk stress og overveldende traumer omtales i sammenhengen, men er ikke tema.

En av prisvinnerne på fjorårets Film Fra Sør-festival var en dokumentar om barnesoldaten som skapte seg et voksenliv i England. Interessen for musikk hadde berget ham. Noen mennesker overlever det umenneskelige og ulevelige.

Nettopp troen på vanlige menneskers muligheter også i krise og katastrofe preger denne teksten.

Bjarte Stubhaug er kjent for sitt forskningsarbeid om kronisk utmattelse, som tidligere leder av Norsk psykiatrisk forening og som kliniker og spaltist.

Her utmerker han seg med en lettfattelig fremstilling, vettuge refleksjoner, jordnær billedbruk og tilgjengelige strategier. 